\title{
Environmental attitudes and behaviors of college students: a case study conducted at a chilean university
}

Actitudes y comportamientos ambientales de estudiantes universitarios: estudio de caso de una universidad chilena

Recibido: 14/07/2013

Revisado: 16/09/2013

Aceptado: 01/11/2013

\author{
Marianne Heyl \\ Universidad Católica de Chile, Chile
}

Emilio Moyano Díaz y

Universidad de Talca, Chile

Luis Cifuentes

Universidad Católica de Chile, Chile

Correspondence to: Emilio Moyano Díaz. 2 Norte 685, University of Talca, Talca, Chile. E-mail: emoyano@utalca.cl

\section{Resumen}

Encouraging the adoption of a pro-environmental behavior is critical in order to reduce the environmental impacts and to move toward a more sustainable future. Higher education plays an important role in training professionals who have an important role in protecting the environment in the future. The aim of this study is to identify whether there are significant differences between college students depending on their diploma of specialization, related to the environment or not, the year in which they are studying and gender. The sample consisted of 383 engineering students in first, third and sixth year, with two instruments designed to measure environmental attitudes and behaviors. Significant differences were found between students pursuing diplomas related to the environment and those who are not. Otherwise, no significant differences were observed between students enrolled in different levels. Perceived effort, positive environmental attitude or perceived positive consequents predict the frequency of pro-environmental behaviors in students, the former (perceived effort, negative) being the most influential variable.

Key words: environmental attitudes, environmental behavior, environmental education, college students crítico para reducir impactos ambientales y encaminarse hacia un futuro sustentable. La educación superior es relevante para la formación de profesionales que jugarán un rol central en la protección del ambiente. El propósito del presente estudio es identificar si hay diferencias en comportamientos proambientales entre los estudiantes universitarios dependiendo de su diploma de especialización (si ambiental o no), nivel de estudios y género. La muestra incluye a 383 estudiantes de ingeniería que cursan 1,3 y 6 año, quienes respondieron instrumentos para medir actitudes y comportamientos proambientales. Se observan diferencias significativas entre quienes cursan diplomas de especialización de tipo ambiental respecto de los otros. No hay diferencias según el año o nivel de estudios. El esfuerzo percibido para la realización de comportamientos pro-ambientales, las actitudes pro-ambientales positivas y la percepción de consecuencias positivas por la realización de quellos, predicen la realización de comportamientos proambientales, donde el esfuerzo percibido es la variable de mayor influencia.

Palabras clave: actitudes ambientales, comportamiento proambiental, educación ambiental, estudiantes universitarios 
Climate change, pollution and depletion of natural resources are some of the most serious environmental problems humanity is currently facing. Experts have demonstrated that our current lifestyle, based on excessive consumption, suggests that we have approached the carrying capacity limit of the Earth (Lenzen, 2001; Walther, Berger \& Sykes, 2005). UNESCO calls for "protecting the planet in order to pass on a sustainable heritage to future generations" (2005, p.2) and mentions many ways to help achieve sustainable development, such as research, technology, financing, production and sustainable consumption.

Amongst these possibilities, education plays a fundamental role, since the concept of education is based implicitly in the idea that systems of beliefs people have about the environment are the roots of the environmental problems (Moyano, Cornejo \& Gallardo, 2011). Thiengkamol and Thiengkamol (2012) mentioned that environmental behavior can be influenced by environmental education, and that environmental education allows for setting a positive attitude, taking responsibility and participating in the protection and conservation of the environment. Additionally, it has been found that environmental education added to environmental regulations determines the interactions between the society and natural resources (Sandoval, 2012).

Cerda, García, Díaz, Núnez and Rojas (2007) note that solutions to environmental problems must be sought not only in technology but also in the ways of perceiving the environment; this in turn translates into a behavioral change. It has been argued that it is necessary to change existing behavioral patterns to achieve a more sustainable future (Rogerson, Bellingham \& Shevtsova, 2009; Steg \& Vlek, 2009) and that behavior analysis can play an important role in solving environmental problems (Lehman \& Geller, 2004). Therefore, environmental education is essential if we want to develop a positive attitude towards the environment and pro-environmental behaviors. In this context, Higher Education plays a fundamental role as it ultimately aims to educate and train professionals who can play an active role in protecting the environment (UNESCO, 2009). These are professionals who will develop their skills in the future, guiding and working to influence various institutions.

Viebahn (2002) mentioned that universities make an important contribution to the development of the society. For this reason, they have an especial responsibility in promoting and creating social and environmental awareness. In the last years, sustainability, including conservation and protection of the environment, has become an important issue in universities, promoting efficiency in their operations and environmental awareness through formal and informal education. A good example of this is that the most widely renowned international universities have sustainability programs or centers for sustainability - the likes of Cambridge, Harvard, MIT, and so on. Currently, universities are writing sustainability reports so as to illustrate how they are improving in this area, although reporting is still at an early stage amongst these institutions (Lozano, 2011). In this research, environmental attitude is understood as an acquired predisposition to respond in a consistently favorable or unfavorable manner with respect to the environment, and for pro-environmental behavior are understand the "actions which contribute towards environmental preservation and conservation" (Kaiser, Wölfing, \& Fuhrer, 1999, p.1).

Unfortunately, studies have found that although many university students show an interest in global problems like climate change - and positive environmental attitude, they do not have any pro-environmental behaviors in their normal activities (Cerda et al., 2007; Müderrisoğlu \& Altanlar, 2011; Rivera-Jacinto \& Rodríguez-Ulloa, 2009), and that relations between environmental attitudes and pro-environmental behaviors are not always linear (Alea García, 2006).

It is known that pro-environmental behaviors are influenced by various internal and external factors (Bamberg \& Moser, 2007; Corral-Verdugo, 2001; Kollmuss \& Agyeman, 2002; Scott \& Willits, 1994) and one of the most studied is environmental attitude as it is considered a strong predictor of pro-environmental behavior (Corral, Fraijo, \& Tapia, 2004; Kaiser et al., 1999; Makki, Abd el Khalick \& Boujaoude, 2003; Moyano Díaz et al., 2011). External factors include, for instance, aspects related to economic, social and/or institutional circumstances. Although an environmental attitude is recognized as a strong predictor of pro-environmental behaviors, a gap between environmental attitude and pro-environmental behavior is demonstrated. Research has attempted to understand this attitude-action gap and which factors influence directly pro-environmental behaviors (Kollmuss \& Agyeman, 2002; Rodríguez-Barreiro et al., 2012) and some research reveals 
that perceived effort is an important factor to be born in mind, as people choose to have pro-environmental behaviors that they perceived demand minimum effort, although they have positive environmental attitudes (Kollmuss \& Ageyman, 2002).

Other factors indirectly influencing pro-environmental behaviors through environmental attitudes are knowledge of the environment (formal education), and gender. Research has shown that students who have studied courses specializing in the environment maintain more pro-environmental attitudes than other students (Meinhold $\&$ Malkus 2005). It was also found that demographic factors such as gender and years of education may have some influence on one's attitude and pro-environmental behaviors (Fernández Rodríguez, \& Carrasquier, 2007; Tuncer, Ertepinar, Tekkaya, \& Sungur, 2005, Uitto, Juuti, Lavonen, Byman, \& Meisalo, 2011). It is understood that older students possess more positive attitudes and proenvironmental behavior in their final stages of their course compared to students in the earlier years (Fernández et al., 2007; Kollmuss \& Ageyman, 2002; Scott \& Willits, 1994; Zarrintaj, Sharifah, \& Binti Abdul, 2011).

There is in Chile a limited number of studies concerning environmental attitudes and pro-environmental behaviors of university students of Agronomy, Commercial Engineering, Public Accounting and Auditing, Forestry Engineering, Law and Architecture. One particular study for this case is the research conducted by Cerda et al. (2007), which highlights the existence of an important gap between attitude and action; students have positive environmental attitudes yet very few of them actually adopt positive environmental actions. It was also found that there are no significant differences in environmental attitudes and pro-environmental behaviors between gender or area of study. In particular, no literature was found which solely referred to engineering students in Chile.

The aim of this research is to study the influences of gender and course level (older and younger students) in university engineering students on environment attitude and pro-environmental behaviors. Likewise this paper seeks to explore the difference between students attending diploma courses related to the environment and the rest ${ }^{1}$

1 The civil engineering programme at a Chilean university enables its students to specialize in different areas (4 semesters, 180 in these two variables. This research ultimately aims to determine which of these three factors: attitude, perceived effort and perceived consequences, influence significantly pro-environmental behaviors in students.

\section{Method}

\section{Population and sample}

This study comprised of 3,231 students in the Faculty of Engineering of a Chilean university. Duration of the engineering degree is six years in a half-year regimen.

For convenience, first, third and sixth year students were asked to take part in the research, so as to make sure the participation of the students. Surveys were sent, via mail, to all students at each of the three selected levels (approximately 1,500 students), yielding a response rate of $25.5 \%$.

The final sample consisted of 383 students, 140 first year, 118 third year and 125 sixth year, of ages ranged between 17 and 26 years $(M=20.6, S D=2.21, M o=18$ years $)$. Table 1 shows the distribution of the final sample for the different demographic variables of interest.

\begin{tabular}{|c|c|c|c|c|c|}
\hline & \multicolumn{3}{|c|}{ 1. Year of degree } & \multirow[b]{2}{*}{ Total } & \multirow[b]{2}{*}{$\%$} \\
\hline & First & Third & Sixth & & \\
\hline Gender Male & 110 & 90 & 93 & 293 & 76.5 \\
\hline Female & 30 & 28 & 32 & 90 & 23.5 \\
\hline Diploma Others & - & 102 & 74 & 316 & 82.5 \\
\hline Environmental & - & 16 & 51 & 67 & 17.5 \\
\hline
\end{tabular}

\section{Instruments}

Two instruments are used: one to assess environmental attitudes and one to assess pro-environmental behavior.

credits), incorporating some courses which can be grouped as "environmental", as they are more related to the environment. These courses deal with current issues surrounding this subject (bioremediation, renewable energy, bio energy, etc.), and they are called: environmental, hydraulic, bioprocess, chemical, and biotechnology diploma courses. These careers have a 6 - semester common plan. 
Environmental attitudes scale. 19 items, of which 3 are original (developed for this research) and the rest (16 items) were adapted from scales used in prior research with university and secondary school students: Scale of pro-environmental attitudes (Castanedo,1995); Scale of Attitude Toward Waste (Fernández, Hueto, Rodríguez \& Marcén, 2003), Scale of Environmental Attitudes Towards Specific Problems (Moreno, Corraliza \& Ruiz, 2005); Scale of Environmental Attitudes (Berenguer, 1998), Scale of Environmental Attitudes (Vega, 2011); Scale of Attitude About The Consumption of Energy -Raviolo, Syracusa \& Herbel (2000)-; Scale of Pro-environmental Behaviors (Martimportugués, Canto, García \& Hidalgo, 2002). Environmental attitudes were rated on a 1 to 6 Likert scale, ranging from (1) "Strongly Disagree" to (6) "Strongly Agree". The items were grouped into six main categories: recycling, energy consumption (save and efficient use of energy), water consumption (save and efficient use of water), transportation (use of public transport or bicycle), responsible consumption of products (use of recycled paper, purchasing organic food or responsible products), and participation in environmental actions. See Appendix A for more detail as to the items.

Pro-environmental behavior scale. 14 items obtained or inspired from research conducted by Moyano et al. (2007), Pato, Ros and Tamayo (2005) and Vozmediano and Guillén (2005) (See Appendix B). Four of these items are original (developed for this research), related to proenvironmental behaviors, which refer to the same categories on the attitude scale. Each item was assigned a frequency of the behavior (from 1 "never" to 6 "always"), the level of effort that the subject perceive (from 1 "least effort or minimal discomfort" to 6 "maximum effort and maximum discomfort"), and finally asks about the positive impact that the subject believes implementation of these behaviors has on the environment, and the positive consequences that the subject perceives (from 1"no positive effect" to 6 "maximum positive effect").

\section{Procedure}

This stage of the research project consists of three stages: the first included piloting the instruments developed for the research and the psychometric properties of each scale. The second stage involved the collection of information needed for the research, and the final stage incorporated an analysis of the information obtained from the applied questionnaires. Hence, the first stage was to pilot the two instruments used in research, with the aim of ensuring its psychometric properties in the final sample. The pilot was conducted with a sample of 60 students from different years of the same career, applied on-line and in person, in order to see whether there were any real differences with the forms of implementing the test.

The results showed no significant difference between groups for the attitude scale $(\mathrm{t}[58]=1.11, \mathrm{p}=0.27)$ or the rest of the instruments; therefore it was concluded that the method of administration is not relevant, as both can be used in order to gather information. Social desirability is also studied in the piloting (abbreviated Marlowe-Crowne Social Desirability Scale). No significant correlations were found between this scale and the environmental attitudes and behavior scales; thus it was decided to eliminate said scale from the questionnaire in the final sample.

As for the Environmental Attitudes Scale, reliability (Cronbach's alpha) obtained in the pilot study was $\alpha=88$. It was consequently decided to apply it without modifications in the final sample $(\mathrm{n}=383)$, and a reliability of $\alpha=.83$ was obtained. With regard to the Pro-environmental Behaviors Scale, results in the pilot study were as follows for each sub-scale: Frequency, $\alpha=.80$; Effort Grade, $\alpha=.83$; Consequences, $\alpha=.95$. The reliability index obtained in the final sample $(\mathrm{n}=383)$ is: Frequency, $\alpha=.73$; Effort Grade, $\alpha=.80$; Positive impact on the environment, $\alpha=.93$. Additionally, an exploratory factorial analysis was conducted for each scale (Appendix C).

Electronic or online means were used to send the questionnaire in the final sample. This was facilitated through the Undergraduate Division. Students were offered an incentive to participate and this was seen as an ideal way to increase response rates. The survey was also administered in person to some students in third $(\mathrm{n}=13)$ and sixth $(\mathrm{n}=20)$ year attending diploma courses which dealt with the environment to ensure the response of students from these diplomas.

\section{Data analysis}

Data was analyzed in STATA11. Descriptive analysis of the sample was carried out in accordance with each variable considered in the research project. 
Differences between items or categories amongst students of different diploma courses and years of degree were compared using the Wilcoxon or Kruskal-Wallis test (nonparametric test), as the sample was not normally distributed in this cases. This analysis was conducted by taking an average for all of the items corresponding to each area, for each student.

A t-test for independent samples was used in order to determine the differences in variables (scales) of environmental attitudes and pro-environmental behaviors between students of different diplomas, considering that data is normally distributed and estimating the effective size of the minimal differences categorized. In terms of the difference between students in different years of study, a variance test (ANOVA univariate) was carried out taking into account the fact that data is normally distributed and that three groups are considered (three different levels in the career).

A hierarchical regression analysis (stepwise) was applied so as to determine which variables predict the frequency of pro-environmental behaviors.

\section{Results}

\section{Environmental attitudes}

Table 2 illustrates the average in categories for the attitude scales and differences with respect to the overall mean by types of diplomas and year of degree. For items, 2-"Separation of Waste by type", 4-"Lights out", 8-"Efficient use of water-and 9-"Taps left open unnecessarily", over $80 \%$ of the answers are found between the maximums scores of the scale ( 5 and 6 points). The total average of the environmental attitudes is 4.5 points out of 6 , showing a relatively high average, and is within the range of holding positive attitudes concerning the environment. It has been noted that the means the recycling, energy and water consumption categories are greater than the average.

There was no significant difference between the grouped items in relation to recycling and energy consumption $(z=-0274, p=.784)$. The same results are found for recycling and water consumption $(z=1670, p=.095)$. Significant differences were found, however, between the means of recycling and the following areas: transport, responsible consumption and participation $(p<.01)$. The same applies with energy consumption and the following areas: transport, responsible consumption and participation $(p<.01)$, and with water consumption $(z=-2.11, p=.035)$. There are no significant differences among the areas of transportation, participation and responsible consumption. These results show that the areas of recycling, energy and water consumption are significantly higher than those of responsible consumption, participation and transportation.

Average environmental attitudes are higher for all categories and items in students taking "environmental" diplomas (except in the item "lights off"). The average environmental attitudes of students taking "environmental" diplomas versus those who did not (mean difference 0.28 ) was significantly different $(t[381]=3.1, p=.019)$, with an effect size (Cohen's d) of 0.42 . This was the same case for the third year students of different diplomas $(t[116]=2.48$, $p=.015)$ with an effect of 0.65 , and those in their sixth year $(t[123]=2.09, p=.0388)$ with an effect size of 40 . No significant differences were found among students attending "environmental" diplomas or other diplomas with regard to their year of study $(F[1.65]=1.19, p=.28$, $F[2.313]=0.05, p=.95)$.

The ANOVA test revealed no significant differences with regard to environmental attitudes $(F[2.381]$ $=0.45, p=.64)$. This suggests that the level of proenvironmentalism does not vary between students in different years. Even so, environmental attitudes regarding the areas of recycling, responsible consumption and participation have a slightly positive trend as students progress through the engineering course. However, this is not the same with regard to energy - which is slightly negative - and transportation - which has a much more notable negative trend - especially in the item referring to the use of the car. In general, environmental attitudes follow a slightly positive trend as the career progresses.

\section{Pro-environmental behaviors}

Table 3 illustrates the average in categories for the proenvironmental behaviors scale and differences with respect to the overall mean by types of diploma courses. Table 4 illustrates the average in categories for the proenvironmental behaviors scale and differences with respect to the overall mean by year of study. The average frequency sub-scale is 3.76 , which shows a slightly positive average, and is within the range of environmentally positive 
Table 2

Average in categories for the attitude scales and differences with respect to the overall mean by types of diplomas and year of degree.

\begin{tabular}{|c|c|c|c|c|c|c|}
\hline \multirow[b]{2}{*}{ No. Ítem } & \multirow[b]{2}{*}{ All } & \multicolumn{2}{|c|}{ Difference by Diploma } & \multicolumn{3}{|c|}{ Difference by Diploma } \\
\hline & & Environmental & Others & First & Third & Sixth \\
\hline Recycling & 4.84 & 0.26 & $-0.05^{\star \star}$ & -0.07 & -0.04 & 0.12 \\
\hline 1 Recycling information & 4.53 & 0.50 & $-0.11^{\star *}$ & -0.25 & 0.08 & $0.20^{*}$ \\
\hline 2 Residues separation & 5.19 & 0.11 & -0.02 & 0.01 & -0.07 & 0.05 \\
\hline 3 Feel good about recycling & 4.82 & 0.15 & -0.03 & 0.02 & -0.13 & 0.11 \\
\hline Energy consumption & 4.88 & 0.13 & -0.03 & -0.02 & 0.03 & -0.01 \\
\hline 4 Turn off lights & 5.63 & -0.01 & 0.00 & -0.06 & 0.01 & 0.05 \\
\hline 5 Feel good about energy savings & 4.79 & 0.23 & -0.05 & 0.00 & -0.07 & 0.07 \\
\hline 6 Energy saving and restrictions & 4.21 & 0.17 & -0.04 & 0.01 & 0.15 & -0.15 \\
\hline Water consumption & 4.95 & 0.16 & $-0.03^{*}$ & -0.09 & 0.12 & -0.02 \\
\hline 7 Water saving and restrictions & 4.11 & 0.28 & -0.06 & 0.00 & 0.04 & -0.05 \\
\hline 8 Water efficiency & 5.28 & 0.19 & -0.04 & -0.24 & 0.21 & $0.07^{\star \star}$ \\
\hline 9 Turn off taps & 5.45 & 0.03 & -0.01 & -0.04 & 0.12 & -0.07 \\
\hline Transportation & 4.28 & 0.22 & -0.05 & 0.11 & -0.03 & -0.10 \\
\hline 10 Air pollution & 4.54 & 0.11 & -0.02 & 0.07 & -0.04 & -0.05 \\
\hline 11 Car use & 3.90 & 0.19 & -0.04 & 0.23 & -0.07 & -0.19 \\
\hline 12 Bicycling or use of public transport & 4.41 & 0.38 & $-0.08^{*}$ & 0.04 & 0.03 & -0.07 \\
\hline Responsible consumption of products & 4.25 & 0.24 & $-0.05^{\star}$ & -0.12 & 0.05 & 0.09 \\
\hline 13 Use of recycled paper & 4.91 & 0.14 & -0.03 & -0.11 & 0.09 & 0.05 \\
\hline 14 Responsible consumption and price & 3.45 & 0.26 & -0.06 & -0.01 & -0.13 & 0.14 \\
\hline \multirow[t]{2}{*}{15 Reduction of packaging less degradable } & 4.75 & 0.16 & -0.03 & -0.15 & 0.12 & 0.05 \\
\hline & \multicolumn{6}{|c|}{ Difference by Diploma } \\
\hline 16 Responsible consumption of products & 3.88 & 0.38 & $-0.08^{*}$ & -0.21 & 0.13 & 0.11 \\
\hline Participation & 4.22 & 0.35 & $-0.07^{\star *}$ & -0.04 & -0.05 & 0.09 \\
\hline 17 Participation in environmental organization & 4.02 & 0.23 & -0.05 & 0.02 & 0.06 & -0.08 \\
\hline 18 Active participation & 4.17 & 0.37 & $-0.08^{\star \star}$ & -0.05 & -0.15 & 0.20 \\
\hline 19 Disposition to inform & 4.48 & 0.45 & $-0.10^{* *}$ & -0.09 & -0.06 & 0.16 \\
\hline Total general & 4.51 & 0.27 & $-0.01^{* *}$ & 0.00 & 0.06 & 0.07 \\
\hline
\end{tabular}

behaviors (albeit it is very low). Similar to the attitude scale, the means for categories of energy consumption and water consumption exceed the mean. The most common behaviors are "closing the taps" and "lights out". While the least common ones are "participation in activities" and "recycled paper".

As for the 'effort' sub-scale the mean is 2.62, which indicates that students are not considered to be putting much effort into exercising this type of behavior. It is noted that means in categories of energy and water consumption are lower than the rest.

The mean in the 'consequences' sub-scale is 4.13, which suggests that students perceive most pro-environmental behaviors as being beneficial to the environment. Once again, means in the categories of recycling and water consumption are greater than the rest.

For students taking an "environmental" diploma course, the frequency subscale reveals significant differences between 
Table 3

Average in categories for the pro-environmental behaviors scale and differences with respect to the overall means by diploma types.

\begin{tabular}{|c|c|c|c|c|c|c|c|c|c|}
\hline \multirow[b]{2}{*}{ No. Ítem } & \multicolumn{3}{|c|}{ Frequency } & \multicolumn{3}{|c|}{ Effort } & \multicolumn{3}{|c|}{ Consequence } \\
\hline & All & $\begin{array}{l}\text { Environ- } \\
\text { mental }\end{array}$ & Others & All & $\begin{array}{l}\text { Environ- } \\
\text { mental }\end{array}$ & Others & All & $\begin{array}{c}\text { Environ- } \\
\text { mental }\end{array}$ & Others \\
\hline Recycling & 3.54 & 0.52 & $-0.12^{\star *}$ & 2.84 & -0.31 & $0.06^{*}$ & 4.46 & 0.18 & -0.04 \\
\hline C1 Recycling paper, glass or cans & 3.77 & 0.16 & -0.02 & 2.47 & 0.11 & -0.03 & 4.27 & 0.01 & 0.00 \\
\hline C2 Recycling at the university & 5.02 & -0.16 & 0.03 & 1.75 & 0.02 & 0.00 & 4.28 & 0.15 & -0.03 \\
\hline Energy consumption & 5.13 & -0.25 & $0.05^{*}$ & 1.74 & 0.11 & -0.02 & 4.52 & 0.08 & -0.01 \\
\hline C3 Turn off the lights & 4.91 & -0.08 & 0.01 & 1.76 & -0.07 & 0.02 & 4.04 & 0.23 & -0.04 \\
\hline C4 Energy efficiency & 5.15 & 0.05 & -0.02 & 2.01 & -0.06 & 0.02 & 4.48 & 0.11 & -0.03 \\
\hline Water consumption & 4.63 & 0.08 & -0.03 & 2.57 & -0.02 & 0.01 & 4.56 & 0.16 & -0.03 \\
\hline C5 Rational use of water & 5.66 & 0.02 & -0.01 & 1.45 & -0.10 & 0.03 & 4.41 & 0.07 & -0.02 \\
\hline C6 Turn off the tap & 4.15 & -0.22 & 0.06 & 3.06 & -0.02 & -0.01 & 4.20 & 0.00 & 0.00 \\
\hline Transportation & 4.78 & -0.27 & 0.08 & 3.01 & 0.05 & -0.03 & 4.23 & 0.08 & -0.02 \\
\hline C7 Use of public transport & 3.52 & -0.17 & 0.05 & 3.11 & -0.08 & 0.01 & 4.18 & -0.09 & 0.02 \\
\hline C8 Bicycling & 2.77 & 0.28 & $-0.06^{* *}$ & 2.98 & -0.02 & 0.00 & 3.93 & 0.09 & -0.02 \\
\hline Responsible consumption of products & 2.40 & 0.27 & -0.06 & 2.84 & -0.09 & 0.02 & 4.28 & 0.09 & -0.02 \\
\hline C9 Use of recycled paper & 2.62 & 0.35 & $-0.07^{\star}$ & 3.26 & -0.09 & 0.02 & 3.85 & 0.15 & -0.03 \\
\hline C10 Buy from pollute companies & 2.51 & 0.10 & -0.01 & 3.34 & 0.19 & -0.04 & 3.39 & 0.00 & 0.01 \\
\hline C11 Buying organic products & 3.54 & 0.39 & $-0.09^{*}$ & 2.51 & -0.09 & 0.02 & 4.19 & 0.13 & -0.02 \\
\hline C12 Buying returnable bottles & 2.82 & 0.31 & $-0.07^{\star}$ & 2.90 & -0.02 & 0.01 & 3.75 & 0.11 & -0.03 \\
\hline Participation & 3.27 & 0.34 & $-0.08^{*}$ & 2.31 & -0.04 & 0.02 & 3.63 & 0.22 & -0.05 \\
\hline C13 Talking about the environment with others & 2.38 & 0.28 & -0.06 & 3.49 & 0.00 & 0.00 & 3.86 & 0.01 & 0.00 \\
\hline C14 Active participation & 3.76 & 0.13 & -0.03 & 2.62 & -0.03 & 0.01 & 4.13 & 0.09 & -0.02 \\
\hline Total & 4.51 & 0.27 & $-0.01^{* *}$ & 0.00 & 0.06 & 0.07 & & & \\
\hline
\end{tabular}

students taking a "environmental" diploma as opposed to those who did not (mean difference $0.16, t[381]=1.66, p=.049$ one-tailed test), with an effect size (Cohen's d) of .24. There is also a significant difference for students attending sixth year and diplomas which focus on the environment $(t[123]=2.32$, $p=.022$ ), with an effect size of .41. This cannot be said for those in their third year. It is also observed that averages of students participating in diplomas with special focus given to the environment are greater than those of students in other degrees, in the areas of recycling, water consumption, responsible consumption and participation. Such significant differences include recycling $(z=2.26, p=.024)$, responsible consumption $(z=2.84, p=.0046)$, and participation $(z=2.18, p=.029)$. There was not a significant difference between students of different diplomas in the 'effort' sub-scale $(t[381]=-0.4$, $p=.69)$. However, the most significant concern referring to 'recycling' showed that students specializing in an environmental diploma are perceived to make less of an effort with regards to adopting recycling practices. The only significant difference occurs with "Recycling paper, glass or cans" $(z=-2.11, p=.035)$ where the average of students studying other diplomas is higher than those specializing in diplomas that deal more so with the environment. Finally, differences in the 'consequences' subscale were not significant difference $(t[381]=0.87, p=.384)$.

The ANOVA test conducted for the three sub-scales; frequency $(F[2.380]=.02, p=.98)$, effort $(F[2.380]=.42$, $p=.09)$ and consequences $(F[2.380]=.04, p=.96)$, reveal no significant difference between each year of degree. Even so, in terms of the 'frequency' sub-scale, the frequency 
Heyl, Moyano Díaz \& Cifuentes

Table 4

Average in categories for the pro-environmental behaviours scale and differences with respect to the overall mean by year of degree.

\begin{tabular}{|c|c|c|c|c|c|c|c|c|c|}
\hline \multirow[b]{3}{*}{ No. Ítem } & \multicolumn{9}{|c|}{ Difference by year of degree } \\
\hline & \multicolumn{3}{|c|}{ Frequency } & \multicolumn{3}{|c|}{ Effort } & \multicolumn{3}{|c|}{ Consequence } \\
\hline & All & $\begin{array}{l}\text { Environ- } \\
\text { mental }\end{array}$ & Others & All & $\begin{array}{l}\text { Environ- } \\
\text { mental }\end{array}$ & Others & All & $\begin{array}{l}\text { Environ- } \\
\text { mental }\end{array}$ & Others \\
\hline Recycling & -0.01 & -0.08 & 0.10 & -0.11 & 0.02 & 0.09 & 0.01 & -0.04 & 0.04 \\
\hline C1 Recycling paper, glass or cans & -0.17 & -0.01 & 0.18 & -0.06 & -0.04 & 0.10 & -0.02 & -0.09 & 0.11 \\
\hline C2 Recycling at the university & 0.15 & -0.16 & 0.01 & -0.16 & 0.08 & 0.08 & 0.03 & 0.01 & -0.04 \\
\hline Energy consumption & -0.04 & 0.05 & -0.01 & 0.02 & -0.11 & 0.08 & 0.04 & -0.08 & 0.03 \\
\hline C3 Turn off the lights & -0.03 & -0.04 & 0.07 & 0.01 & -0.15 & 0.13 & 0.03 & -0.08 & 0.05 \\
\hline C4 Energy efficiency & -0.04 & 0.14 & -0.10 & 0.04 & -0.07 & 0.03 & 0.05 & -0.07 & 0.02 \\
\hline Water consumption & -0.13 & 0.06 & $0.06^{*}$ & 0.05 & -0.11 & 0.06 & -0.02 & 0.04 & -0.02 \\
\hline C5 Rational use of water & -0.12 & 0.10 & 0.02 & 0.03 & -0.16 & 0.13 & -0.01 & 0.00 & 0.01 \\
\hline C6 Turn off the taps & -0.14 & 0.03 & $0.10^{\star \star}$ & 0.06 & -0.05 & -0.01 & -0.03 & 0.07 & -0.04 \\
\hline Transportation & 0.31 & -0.08 & $-0.24^{\star *}$ & -0.24 & 0.01 & 0.23 & 0.01 & -0.01 & 0.00 \\
\hline C7 Use of public transport & 0.43 & -0.16 & $-0.27^{\star *}$ & -0.31 & 0.02 & $0.29^{*}$ & -0.04 & 0.02 & 0.03 \\
\hline C8 Bicycling & 0.20 & 0.01 & -0.21 & -0.18 & 0.00 & 0.17 & 0.07 & -0.04 & -0.02 \\
\hline Responsible consumption of products & 0.03 & 0.01 & -0.04 & -0.04 & -0.09 & $0.13^{*}$ & 0.04 & -0.06 & 0.03 \\
\hline C9 Use of recycled paper & -0.06 & 0.09 & -0.03 & 0.05 & -0.08 & 0.03 & -0.02 & 0.02 & 0.01 \\
\hline C10 Buy from pollute companies & 0.00 & -0.18 & 0.18 & -0.10 & -0.05 & 0.15 & 0.00 & -0.04 & 0.04 \\
\hline C11 Buying organic products & 0.21 & 0.09 & $-0.30^{*}$ & -0.14 & -0.15 & $0.29^{*}$ & 0.11 & -0.08 & -0.03 \\
\hline C12 Buying returnable bottles & -0.05 & 0.05 & 0.00 & 0.03 & -0.09 & 0.05 & 0.07 & -0.15 & 0.08 \\
\hline Participation & -0.13 & 0.04 & 0.09 & 0.05 & -0.10 & 0.05 & -0.02 & 0.09 & -0.07 \\
\hline C13 Talking about the environment with others & -0.25 & 0.00 & $0.24^{*}$ & 0.12 & -0.12 & 0.00 & -0.06 & 0.07 & -0.01 \\
\hline C14 Active participation & -0.02 & 0.07 & -0.06 & -0.03 & -0.07 & 0.10 & 0.02 & 0.11 & -0.12 \\
\hline Total & 0.01 & 0.00 & -0.01 & -0.04 & -0.06 & 0.11 & 0.01 & -0.02 & 0.01 \\
\hline
\end{tabular}

of environmental behaviors related to recycling, energy consumption, water consumption and participation have a tendency to be slightly more positive as the career progresses, unlike transportation which has a much greater negative tendency.

In the 'effort' sub-scale, no significant differences are identified between the categories, and it could highlight the differences of two behaviors: "Using public transport" (chi2[2] $=7.39, p=.025$ ), and "buying organic products" (chi2[2] =7.34, $p=.026$ ). In both cases, students in later years of the career perceived themselves as making a greater effort than those in first year.
The 'consequences' sub-scale shows that no distinguished variations are found during the years of study, but the biggest differences are apparent when considering the level of participation.

\section{Differences by gender}

Significant differences were found for the environmental attitudes variable with regards to gender, but only among students in their first year. More pro-environmentalism was observed in females than in males $(t[138]=-2.06, p=.04)$ with an effect size of .43 . No significant differences were found for males with regards to the year of study $(F[2,290]=1.15$, 
$p=.32$ ), although it is noted that environmental attitudes have a positive increase tendency in the first year with a mean of 4.45, a mean of 4.55 in third year and a mean of 4.58 in sixth year. No significant differences regarding career year were found amongst females $(F[2,87]=0.51, p=$ $.60)$, but it has been observed that attitudes with regards the environment decline as they progress through their studies. They begin with an average of 4.73 , drop to an average of 4.62 in third year and again slightly to 4.58 in sixth year.

\section{Influential variables in the frequency of the pro-environmental behavior}

A regression analysis was conducted with frequency of proenvironmental behavior as the dependent variable, and the environmental attitude, effort and perceived consequences as independent variables. These independent variables were chosen as they are potential influential variables of pro-environmental behaviors.

In the model, the regression coefficient obtained was $40 \%$. All three variables were found to predict the frequency, effort $(b=-0.51, p=.000)$, environmental attitude $(b=0.40, p=.000)$ and consequences $(b=0.18$, $p=.000)$. As the effort perceived by the person decreases, both environmental attitude and the perceived consequence increase, as is the case of frequency of the behavior.

The same procedure was performed for each category. It was found that all three variables significantly predict the frequency $(p<.01)$, for five of the six categories: recycling (regression coefficient of 30\%), energy (regression coefficient of 29\%), water (regression coefficient of $25 \%$ ), responsible consumption (regression coefficient of $29 \%$ ) and participation (regression coefficient of 41\%). For transport, the regression coefficient obtained was $46 \%$, and only two variables were found to significantly predict the frequency $(p<.01)$. Results by categories are shown in table 5 .

\section{Discussion}

This research suggests that university undergraduate engineering students on average have positive environmental attitudes, as has been shown in other studies with third level students (Aydin \& Çepni, 2010; Cerda et al., 2007; Müderrisoğlu \& Altanlar, 2011). Benefits are rightly understood to affect the environment positively and pro-environmental behaviors are present on a behavioral level, albeit not very often.

\begin{tabular}{|c|c|c|c|c|}
\hline \multicolumn{5}{|c|}{$\begin{array}{l}\text { Table } 5 \\
\text { Regression coefficient obtained for } \\
\text { independent variables, by categories. }\end{array}$} \\
\hline \multirow[b]{2}{*}{ No. } & \multirow[b]{2}{*}{ Categories } & \multicolumn{3}{|c|}{ Independent variables } \\
\hline & & $\begin{array}{c}\text { Environmental } \\
\text { Attitude }\end{array}$ & $\begin{array}{c}\text { Perceived } \\
\text { Effort }\end{array}$ & $\begin{array}{c}\text { Perceived } \\
\text { Consequences }\end{array}$ \\
\hline 1 & Recycling & 0.36 & -0.46 & 0.13 \\
\hline 2 & Energy & 0.21 & -0.44 & 0.10 \\
\hline 3 & Water & 0.25 & -0.27 & 0.08 \\
\hline 4 & $\begin{array}{l}\text { Responsible } \\
\text { consumption }\end{array}$ & 0.47 & -0.08 & 0.16 \\
\hline 5 & Participation & 0.49 & -0.17 & 0.22 \\
\hline 6 & Transport & 0.2 & -0.51 & -0.001 \\
\hline
\end{tabular}

For the full sample of students, recycling, water and energy consumption are those with higher average scores on environmental attitudes. Likewise, the aforementioned behaviors are most frequently observed in relation to water and energy consumption, while the least observed ones are those related to responsible consumption and participation. This is also consistent with findings in other studies (Pruneau et al., 2006, Rivera-Jacinto \& Rodriguez - Ulloa, 2009; González Lomeli, Frías Armenta \& Corral Verdugo 2003).

Therefore, actions such as switching off the lights and turning off the taps are more frequent in this research, and the least frequent ones are those related to purchasing recycled products or those of little harm to the environment. Actions that are carried out less frequently are in many cases those that perceived to require more effort, such as cycling, buying organic products and participating in activities related to the environment. These findings are consistent with data collected in other research (Kaiser, 1998; Kaiser et al., 1999). Furthermore, the actions that are most frequently carried out are perceived to have positive consequences for the environment, with the exception of recycling and the use of recycled paper due to shortage of this product in Chile, which is also more expensive than plain paper as well as organic products. Students attending diploma courses related with the environment have more positive attitudes than those undergoing other diplomas, especially on issues related to recycling and participation. The energy category is different where the average is slightly lower. Students taking diplomas with a focus on 
the environment were more frequently deemed to be more pro-environmental in most categories, except those related to energy consumption and transportation. This difference concerning energy (behavior) could be due to the fact that there are diploma courses which address topics on energy (renewable energy and sustainable energy); these are not considered to be connected to the "environment" in this research but could influence pro-environmental behavior in other diplomas and study areas which are not related to the environment. With regard to the differences found in transport, use of the bicycle by those attending diploma courses was minimal related to the environment because they also perceive fewer benefits associated to this behavior as do students from other diplomas.

This improved attitude and pro-environmental behavior amongst students following diploma courses related more to the environment ties in closely with the work of Meinhold and Malkus (2005). However, it is yet to be determined whether there is a causal relationship between environmental courses and better environmental attitude and behavior as a consequence, as there may be an "environmental" predisposition or students may hold interests concerning the environment prior to their study, which has subsequently led them to study diplomas related to the environment.

With regard to the level or year of the career, there are no significant differences in environmental attitudes and behavior. Such results are similar to the research conducted by Cerda et al, (2007) and Makki et al, (2003). Therefore, this result suggests that the civil engineering curriculum appears to not be generating any significant impact with regards the attitudes and pro-environmental behaviors of students, as previously expected. Studying for longer within the current curriculum format has no effect on the attitudes and pro-environmental behaviors amongst engineering students. Hence, if engineering professionals from this university are to be recognized and known for excellence in the environmental field, environmental education should be integrated across the entire curriculum. It is worth mentioning that the positive trend related to recycling during the years of the course may be due to the recycling program in place both at the university and in the School of Engineering.

Differences discovered in gender in this study vary from previous research (Tuncer et al., 2005). Here, the only existing differences are in the environmental attitudes among first year students, where women have more positive environmental attitudes than men, but this difference disappears as they progress in the career.

In conclusion, students have positive environmental attitudes, but not reflected in a corresponding or proportional frequency of conducting environmental behavior, especially the categories which relate to responsible consumption and participation. Upon conducting regression analysis, it is noted that the three variables - effort, attitude and consequences - predict the frequency of pro-environmental behaviors. The model shows that the most influential variable is the effort perceived (negative), then the environmental attitude (positive) and finally the consequences (positive). In analyzing each of the areas, the model was found to be similar to recycling and energy, where the effort is identified as the factor with the greatest influence. This is not the case with regard to responsible consumption and participation, where environmental attitude is often a better predictor of the effort or the consequences. As for transportation, the model does not consider the variable consequences to be significant, and shows that the effort required is the most influential variable in the frequency of action, which is consistent with the local reality, where the consequences of using of the car are well recognized but still people prefer to use the car than public transportation.

It has also been noted in some cases that, despite the fact that students have positive environmental attitudes, their actions or behaviors do not relate to the same frequency. This can be drawn from the fact that pro-environmental behavior is also affected by other factors not considered in this research. Said factors include social norms and moral obligations as proposed by Fishbein and Ajzen (RiveraJacinto \& Rodriguez-Ulloa, 2009). Additionally, contextual or external factors, such as having adequate infrastructure, technical or logistical facilities (essential in recycling) and availability of products in the country - as is the case with organic products, or products which cause less damage to the environment (Steg \&Vlek, 2009).

In this study we have only identified some factors related mostly to the demographics factor, environmental knowledge, environmental attitude and perceived effort and consequences. For further research, it is also important to study the influence of other factors like social norms, the role models and mentors and the everyday life experiences - positive experiences or observation of destruction of valued places in fostering pro- 
environmental attitudes (Chawla \& Flanders, 2007). All of these fields of research can provide valuable information in order to develop better and more effective programs to foster pro-environmental behaviors in students.

\section{References}

Alea García, A. (2006). Diagnóstico y potenciación de la educación ambiental en jóvenes universitarios. Odiseo, Revista Electrónica de Pedagogía. México, 3(6), 1-29.

Aydin, F., \& Çepni, O. (2010). University students' attitudes towards environmental problems: A case study from Turkey. International Journal of the Physical Sciences, 5(17), 2715-2720.

Bamberg, S., \& Möser, G. (2007). Twenty years after Hines, Hungerford, and Tomera: A new meta-analysis of psycho-social determinants of pro-environmental behaviour. Journal of Environmental Psychology, 27(1), 14-25. doi: 10.1016/j.jenvp.2006.12.002

Berenguer, J. (1998). Actitudes y creencias ambientales. Una explicación psicosocial del comportamiento ecológico. PhD, diss., Universidad Autónoma de Madrid.

Castanedo, C. (1995). Escala para la evaluación de las actitudes pro-ambientales (EAPA) de alumnos universitarios. Revista Complutense de Educación, 6(2), 253-278

Cerda, A., García, L., Díaz, M., Núñez, N., \& Rojas, J. (2007). Perfil y Conducta Ambiental de los Estudiantes de la Universidad de Talca, Chile. Panorama Socioeconómico, 25(35), 148-159.

Chawla, L. \& Flanders C. D. (2007). 'Education for strategic environmental behavior', Environmental Education Research, 13(4), 437-452

Corral-Verdugo, V. (2001). Comportamiento Proambiental: Una Introducción al Estudio de las Conductas Protectoras del Ambiente. Santa Cruz de Tenerife, España.

Corral, V., Fraijó, B., \& Tapia, C. (2004). Propensiones psicológicas en niños de sexto grado de primaria. Validez de un instrumento. Anuario de Investigaciones Educativas, 7, 31-44.

Fernández, R., Hueto, A., Rodríguez, L., \& Marcén, C. (2003). ¿Qué miden las escalas de actitudes? Análisis de un ejemplo para conocer la actitud hacia los residuos urbanos. Ecosistemas, 12, 1-18.

Fernández, R., Rodríguez Barreiro, L. M., \& Carrasquer, J. (2007). Evaluation of Environmental Attitudes:
Analysis and Results of a Scale Applied to University Students. Science Education, 91, 908-100. doi: 10.1002/sce.20218

González Lomelí, D., Frías Armenta, M., \& Corral Verdugo, V.,(2003). Percepción de riesgos, conducta pro ambiental y variables demográficas en una comunidad de Sonora México. Región y Sociedad, 15(26), 49-72.

Kaiser, E. (1998). A general measure of ecological behavior. Journal of Applied Social Psychology, 28(395). doi: 10.1111/j.1559-1816.1998.tb01712.x

Kaiser, E., Wolfing, S., \& Fuhrer, U. (1999). Environmental attitude and ecological behavior. Journal of Environmental Psychology, 19, 1-19. doi: 10.1006/ jevp.1998.0107

Kollmuss, A., \& Agyema, J. (2002). Mind the Gap: why do people act environmentally and what are the barriers to pro-environmental behavior. Environmental Education Research, 8(3), 239-260. doi: 10.1080/13504620220145401

Lehman, F. K., \& Geller, E.S. (2004). Behavior analysis and environmental protection: accomplishments and potential for more. Behavior and Social Issues, 13(1), 13-32

Lenzen, M., \& Murray, S. (2001). A modified ecological footprint method and its application to Australia Ecological Economics. Ecological Economics, 37(2), 229-255.

Lozano, R. (2011). The state of sustainability reporting in universities. International Journal of Sustainability in Higher Education, 12(1), 67-78. doi: 10.1108/14676371111098311

Makki, M.H., Abd-el-Khalick, F., \& Boujaoude, S. (2003). Lebanese Secondary School Students' Environmental Knowledge and Attitudes. Environmental Education Research, 9(1), 21-33. doi: 10.1080/13504620303468

Martimportugués, C., Canto, J. M., García, M. A., \& Hidalgo, C. (2002). Evaluación de las actitudes ambientales relacionadas con la conservación y el consumo de agua en escolares malagueños. Medio Ambiente y Comportamiento Humano, 3(2), 119-143

Meinhold, J. L., \& Malkus, A. J. (2005). Adolescent environmental behaviors: Can knowledge, attitudes, and self-efficacy make a difference? Environment and Behavior, 37(4), 511-532. doi: 10.1177/0013916504269665 
Moreno, M., Corraliza, J., \& Ruiz, J. (2005). Escala de actitudes ambientales hacia problemas específicos. Psicothema, 17(3), 502-508.

Moyano Díaz, E., Cornejo, F. \& Gallardo, I. (2011). Creencias y conductas ambientales, liberalismo económico y felicidad. Acta Colombiana de Psicología 14 (2), 69-77.

Moyano, E., Encina, Y., \& Vicente, D. (2007). Evaluación del Sistema Nacional de Certificación Ambiental de Establecimientos Educacionales (SNCAE) en Chile: Operatoria e Impacto. Psicología para América Latina, 10, 335-348.

Müderrisoğlu, H., \& Altanla, A. (2011). Attitudes and behaviors of undergraduate students toward environmental issues. International Journal of Environmental Science and Technology, 8(1), 159-168.

Pato, C., Ros, M., \& Tamayo, A. (2005). Creencias y Comportamiento Ecológico: un estudio empírico con estudiantes brasileños. Medio Ambiente y Comportamiento Humano, 6(1), 5-22.

Pruneau, D., Doyon, A., Langis, J., Martin, L., Ouellet, E., \& Boudreau, G. (2006). The process of change experimented by teachers and students when voluntarily trying environmental behaviours. Applied Environmental Education and Communication, 5 (1), 33-40.

Raviolo, A., Siracusa, P., \& Herbel, M. (2000). Desarrollo de actitudes hacia el cuidado de la energía: experiencia en la formación de maestro. Enseñanza de las ciencias, $18,79-86$.

Rivera-Jacinto, M., \& Rodríguez-Ulloa, C. (2009). Actitudes y comportamientos ambientales en estudiantes de enfermería de una universidad pública del norte de Perú. Revista Peruana de Medicina Experimental y Salud Pública, 26(3), 338-342.

Rogerson, R., Bellingham, R., \& Shevtsova, Y. (2009). Changing behaviour and attitudes to sustainability: A Report for the department of enterprise trade and investment. European Sustainable Competitiveness Programme for Northern Ireland

Sandoval, M. (2012). Comportamiento sustentable y educación ambiental: una visión desde las prácticas culturales. Revista Latinoamericana de Psicologia, 44(1), 181-196.
Scott, D., \& Willits, F. K. (1994). Environmental attitudes and behavior. Environment and Behavior, 26, 239260. doi: 10.1177/001391659402600206

Steg, L., \& Vlek, C. (2009). Encouraging pro-environmental behaviour: An integrative review and research agenda. Journal of Environmental Psychology, 29(3), 309-317. doi: 10.1016/j.jenvp.2008.10.004

Thiengkamol, N., \& Thiengkamol, T. (2012). Factor Affecting Villagers Participation in Community Environment Development. Mediterranean Journal of Social Sciences 3(11), 536 - 540 doi: 10.5901/ mjss.2012.v3n11p535

Tuncer, G., Ertepinar, H., Tekkaya, C., \& Sungur, S. (2005). Environmental attitudes of young people in Turkey: Effects of school type and gender. Environmental Education Research, 11(2), 215-223. doi: 10.1080/1350462042000338379

Uitto, A., Lavonen, J., Byman, R., Juuti, K., \& Meisalo, V. (2011). Secondary school students' interests, attitudes and values concerning school science related environmental issues in Finland. Environmental Education Research, 17(2), 167-186. doi: 10.1080/13504622.2010.522703

UNESCO (2009). Politicas, estrategias y planes regionales, subregionales y nacionales en educación para el desarrollo sostenible y la educación ambiental en América Latina y el Caribe. Santiago, Chile: Oficina Regional de Educación de la UNESCO para América Latina y El Caribe.

Vega, M. (2011). Environmental profile of college students and influencers of their environmental behavior: study oriented on the development of efficient environmental policies. (Tesis inédita de maestría). Pontificia Universidad Católica, Santiago de Chile.

Viebahn, P. (2002). An environmental management model for universities: from environmental guidelines to staff involvement. Journal of Cleaner Production, 10, 3-12. doi: 10.1016/S0959-6526(01)00017-8

Vozmediano, L., \& Guillén, C. (2005). Escala de Nuevo Paradigma Ecológico: propiedades psicométricas con una muestra española obtenida a través de Internet. Medio Ambiente y Comportamiento Humano 6 (1), 37-49.

Walther, G., Berger, S., \& Skyes, M. (2005). An ecological 'footprint' of climate change. Proceedings of the Royal 
Society London, Biological Series, 272, 1427-1432. doi: 10.1098/rspb.2005.3119

Zarrintaj, A., Sharifah, Z., Binti, Z., \& Abdul, S. (2011). Influence of Age and Level of Education on Environmental Awareness and Attitude: Case Study on Iranian Students in Malaysian Universities. The Social Sciences, 6, 15-19. doi: 10.3923/ sscience.2011.15.19

\section{APPENDIX}

\section{A. Scale of environmental attitude}

\begin{tabular}{|c|c|c|}
\hline No. & Ítems & Reference \\
\hline 1 & $\begin{array}{l}\text { I would like to inform people about the importance } \\
\text { of pollution and environmental problems. }\end{array}$ & $\begin{array}{l}\text { Castanedo, C. } \\
\text { (1995) }\end{array}$ \\
\hline 2 & $\begin{array}{l}\text { When I need to decide between buying two similar } \\
\text { products, I tend to choose the one which results } \\
\text { less damaging for people or the environment. }\end{array}$ & Vega, M. (2011) \\
\hline 3 & $\begin{array}{l}\text { I am not willing to save energy if I have to } \\
\text { restrict the use of appliances such as TVs or air } \\
\text { conditioning. }\end{array}$ & $\begin{array}{l}\text { Castanedo, C. } \\
\text { (1995) }\end{array}$ \\
\hline 4 & $\begin{array}{l}\text { I do not care to leave open a tap unnecessarily, } \\
\text { for example to brush my teeth or leave it running } \\
\text { after use. }\end{array}$ & $\begin{array}{l}\text { Moreno, M., } \\
\text { Corraliza, J., \& } \\
\text { Ruiz, J. (2005) }\end{array}$ \\
\hline 5 & When I recycle I feel good. & $\begin{array}{l}\text { Moreno, M., } \\
\text { Corraliza, J., \& } \\
\text { Ruiz, J. (2005) }\end{array}$ \\
\hline 6 & $\begin{array}{l}\text { I am willing to reduce the consumption of } \\
\text { unnecessary products and packaging of difficult } \\
\text { degradation. }\end{array}$ & $\begin{array}{l}\text { Fernández, } \\
\text { R., Hueto, A., } \\
\text { Rodríguez, L., \& } \\
\text { Marcén, C. (2003) }\end{array}$ \\
\hline 7 & $\begin{array}{l}\text { I am not willing to throw residues into different bins } \\
\text { depending on its type (i.e. organic, paper, plastics, } \\
\text { or glass). }\end{array}$ & $\begin{array}{l}\text { Fernández, } \\
\text { R., Hueto, A., } \\
\text { Rodríguez, L., \& } \\
\text { Marcén, C. (2003) }\end{array}$ \\
\hline 8 & $\begin{array}{l}\text { I would like to take on an active role in finding } \\
\text { solutions to problems originating pollution. }\end{array}$ & $\begin{array}{l}\text { Castanedo, C. } \\
(1995)\end{array}$ \\
\hline 9 & $\begin{array}{l}\text { I am willing to use the bike or take the bus to go to } \\
\text { the university, to reduce air pollution. }\end{array}$ & $\begin{array}{l}\text { Berenguer, J. } \\
\text { (1998) }\end{array}$ \\
\hline 10 & I feel good when I save energy. & $\begin{array}{l}\text { Raviolo, A., } \\
\text { Siracusa, P., \& } \\
\text { Herbel, M. (2000) }\end{array}$ \\
\hline 11 & $\begin{array}{l}\text { I am willing to use the washing machine or } \\
\text { dishwasher with full load to save water. }\end{array}$ & * \\
\hline 12 & $\begin{array}{l}\text { I would rather use the car to go to university } \\
\text { instead of the bus or subway. }\end{array}$ & $\begin{array}{l}\text { Martimportugués, } \\
\text { C., Canto, J. M., } \\
\text { García, M. A., \& } \\
\text { Hidalgo, C. (2002) }\end{array}$ \\
\hline 13 & $\begin{array}{l}\text { If I could I will give money, time or both to an } \\
\text { organization that works to improve environmental } \\
\text { quality. }\end{array}$ & $\begin{array}{l}\text { Castanedo, C. } \\
\text { (1995) }\end{array}$ \\
\hline 14 & $\begin{array}{l}\text { I am willing to use recycled paper because fewer } \\
\text { trees will be cut. }\end{array}$ & $\begin{array}{l}\text { Fernández, } \\
\text { R., Hueto, A., } \\
\text { Rodríguez, L., \& } \\
\text { Marcén, C. (2003) }\end{array}$ \\
\hline
\end{tabular}




\begin{tabular}{|l|l|l|}
\hline 15 & $\begin{array}{l}\text { I am willing to turn off the lights that I am not using } \\
\text { them in order to save energy. }\end{array}$ & * \\
\hline 16 & I would like to know more about recycling. & $\begin{array}{l}\text { Fernández, } \\
\text { R., Hueto, A., } \\
\text { Rodríguez, L., \& } \\
\text { Marcén, C. (2003) }\end{array}$ \\
\hline 17 & $\begin{array}{l}\text { I do not feel responsible of the air pollution since } \\
\text { the contribution of using a personal car is very low. }\end{array}$ & $\begin{array}{l}\text { Moreno, M., } \\
\text { Corraliza, J., \& } \\
\text { Ruiz, J. (2005) }\end{array}$ \\
\hline 18 & $\begin{array}{l}\text { I am willing to take shorter showers in order to } \\
\text { save water. }\end{array}$ & * \\
\hline 19 & $\begin{array}{l}\text { I do not like to buy organic food (without fertilizers } \\
\text { and pesticides) because they are more expensive } \\
\text { or harder to find. }\end{array}$ & $\begin{array}{l}\text { Castanedo, C. } \\
\text { (1995) }\end{array}$ \\
\hline
\end{tabular}

${ }^{*}$ Items 11,15 y 18 were created for this scale.

\section{B. Pro-environmental behaviour Scale.}

\begin{tabular}{|l|l|}
\hline C1. I take part in activities that care for the environment. & $\begin{array}{l}\text { Pato, C., Ros, } \\
\text { M., \& Tamayo, A. } \\
(2005)\end{array}$ \\
\hline $\begin{array}{l}\text { C2 I talk about the importance of the environment with } \\
\text { others. }\end{array}$ & $\begin{array}{l}\text { Pato, C., Ros, } \\
\text { M., \& Tamayo, A. } \\
(2005)\end{array}$ \\
\hline $\begin{array}{l}\text { C3. I prefer to consume drinks that come in returnable } \\
\text { bottle. }\end{array}$ & $\begin{array}{l}\text { Moyano, E., } \\
\text { Encina, Y., \& } \\
\text { Vicente, D. (2007). }\end{array}$ \\
\hline C4. I buy organic products. & * \\
\hline $\begin{array}{l}\text { C5. I avoid using products that are made by a company } \\
\text { that is polluting the environment. }\end{array}$ & $\begin{array}{l}\text { Pato, C., Ros, } \\
\text { M., \& Tamayo, A. } \\
(2005)\end{array}$ \\
\hline C6. I use recycled or certified paper. & * \\
\hline $\begin{array}{l}\text { C7. I walk or use the bike when going to places near my } \\
\text { home. }\end{array}$ & * \\
\hline $\begin{array}{l}\text { C8. I usually travel to university by subway, bus or } \\
\text { walking. }\end{array}$ & * \\
\hline $\begin{array}{l}\text { C11. I close the taps if the water is running. } \\
\text { doing other things. }\end{array}$ & $\begin{array}{l}\text { Moyano, E., } \\
\text { Encina, Y., \& } \\
\text { Vicente, D. (2007). }\end{array}$ \\
\hline C10. save water whenever I can. & $\begin{array}{l}\text { Pato, C., Ros, } \\
(2005)\end{array}$ \\
\hline $\begin{array}{l}\text { Pato, C., Ros, } \\
\text { M., \& Tamayo, A. } \\
(2005)\end{array}$
\end{tabular}

\begin{tabular}{|l|l|}
\hline \multirow{2}{*}{$\begin{array}{l}\text { C12. I turn off the lights when I leave a room or there is } \\
\text { enough natural light. }\end{array}$} & $\begin{array}{l}\text { Moyano, E., } \\
\text { Encina, Y., \& } \\
\text { Vicente, D. } \\
\text { (2007);Vozmediano } \\
\text { \& Guillén (2005). }\end{array}$ \\
\hline \multirow{3}{*}{ C13. I contribute to the recycling campaigns at university. } & Moyano, E., \\
& Encina, Y., \& \\
& Vicente, D. (2007). \\
\hline C14. I recycle paper, glass and cans. & Moyano, E., \\
& Encina, Y., \& \\
& Vicente, D. (2007). \\
& Vozmediano \& \\
& Guillén (2005). \\
\hline
\end{tabular}

* These items were created for this scale.

\section{Exploratory factorial analysis for Pro-environmental behaviour scale.}

One principal component analysis (eigenvalues greater than 1 and loading factor $\geq 0.3$ ) revealed four main factors, that can be denominated participation and information (items $1,3,5,17,18,19)$ responsible consumption of resources (ítems 2, 4, 7, 8, 9), transportation (ítems 10, 11 and 12) and responsabile consumpion of products (ítems 13, 14, $15,16)$.

And for the pro-environmental behaviour scale the analysis reveal three main factor for the sub-scale of frecuency and effort; participation, recycling and responsible consumption, (items C1, C2, C9, C10, C11 y C14); water and energy use (C3, C4, C5 y C6), and transportation (C7 y C8). 